頭位変換法での良性発作性頭位めまい症治療

板谷 隆義1) - 北野 博也 ${ }^{1)} \cdot$ 矢沢代四郎1) 坚玉 章1)

駒田 一朗2) - 鈴木 幹男 3$) \cdot$ 井上 秀蔵4) 北嶋 和智1)

\title{
Benign Paroxysmal Positional Vertigo Treated with Maneuvers to Change Head Position
}

\author{
Takayoshi Itaya, Hiroya Kitano, Yoshiro Yazawa, \\ Akira Kodama and Kazutomo Kitajima \\ (Shiga University of Medical Science) \\ Ichiro Komada \\ (Koka Public Hospital) \\ Mikio Suzuki \\ (Kusatsu Central Hospital) \\ Shuzo Inoue \\ (Takashima General Public Hospital
}

\begin{abstract}
Several new maneuvers have been described recently which treat benign paroxysmal positional vertigo with head rotations to induce canal debris to move into the utricle. This study compared two maneuvers, the Particle Repositioning Maneuver (PRM) reported by Parnes and Price-Jones and the Liberatory Maneuver (LM) reported by Semont, with treatment by medication only. Thirteen of 15 patients $(86.7 \%)$ treated with PRM and 8 of 9 (88.9\%) treated with LM showed improvement after two weeks. These figures are higher than those obtained by medication alone, 8 out of $26(30.8 \%)$. The superiority of these maneuvers appeared to be in the reduction of the duration of the disease, since an $80 \%$ success rate was obtained by medication alone after three months. LM seemed to be a better technique than PRM, since three patients who were not improved with PRM were then treated with LM, and two were cured and one improved.
\end{abstract}

Key words : benign paroxysmal positional vertigo, particle repositioning maneuver, liberatory maneuver

はじめに

良性発作性頭位めまい症(以下 BPPV)は末梢性めま いのらちメニェール病とならんで臨床でよく遭遇する疾 患である. 最近, 後半規管内に浮遊する小片が移動する
際に BPPVの症状を引き起こすといら canalithiasis の 概念を背景に, 浮遊する小片を頭位変換にて卵形囊に排 出させ治療する方法が報告されている12).

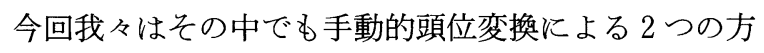

1）滋賀医科大学耳鼻咽喉科学教室

3）草津中央病院耳鼻咽喉科
2）公立甲賀病院耳鼻咽喉科

4）公立高島総合病院耳鼻咽喉科 
法一1993年 Parnes ら1) の報告した Particle Repositioning Maneuver (以下 PRM) と1988年 Semont ら ${ }^{2)}$ が報告 した Liberatory Maneuver (以下 LM)にてBPPV の治 療を行い従来の治療効果と比較検討した。

\section{対象と方法}

対象は平成 6 年 5 月から 11 月まで滋賀医科大学和よ び関連病院耳鼻咽喉科を訪れためまい患者のらち， BPPV と診断された 23 例である。診断基準は1987年日 本平衡神経科学会編めまいの診断基準化のための資料3) 飞準拠した。 23例のうち17例は PRMを， 6 例は LM を施行した，手技の選択は無作為に決定したが，PRM 施行群中 3 例は無効であったため LM を施行し， LM 施行群は 9 例となった。これらの手技による治療効果を 判定するために, 平成 5 年 1 年間に滋賀医科大学耳鼻咽 喉科を受診, 同疾患と診断され薬物治療を主体とした治 療をらけた26例(非施行群)との間で比較検討した.

方法は, 問診・聴力検查执よび一般的理学的検查の後, 頭位眼振・頭位変換眼振検査を行いBPPM と診断すれ ばただちにPRM またはLMを行った。ただし，頭位 変換眼振検查にて上向き(背地性)の眼振を認めた場合や 眼振持続が30秒以上にわたる場合は CT や MRI 検査を 施行し明らかな中枢疾患がないことを確認した上でこれ らの手技を行った。

患側の決定は原則として眼振の出現する頭位で下にな る側を患側とした．座位から両懸垂頭位とも眼振が生じ る場合持続時間が長い方を患側とした。

Particle Repositioning Maneuver

図 1 は Parnes and Price-Jones ${ }^{1)}$ の文献からの改変で ある。患側を右とした場合，まず座位から右下 $45^{\circ}$ の 懸垂頭位をとる，この時患者は回転性めまいを訴光，回 旋性成分の多い眼振が認められる. 眼振が終了した時点 から 2,3 分その頭位を維持する. 次に右下懸垂頭位か ら左下 $45^{\circ}$ の懸垂頭位へとゆっくり頭位を変換してい く、この時同様の回転性めまいと眼振が生じる場合があ る. 次に左肩を始いて頭位が仰臥位から $135^{\circ}$ になるよ らにゆっくり変換する.この頭位も数分維持した後ゆっ くりと座位へと起きあがる. 座位ではわずかに頸を前屈 する.

\section{Liberatory Maneuver}

図 2 は1994年 Brandt ら 4 ) の文献を患側が右になるよ らに改变したものである. 患側を右とするとまず頭位を (a)
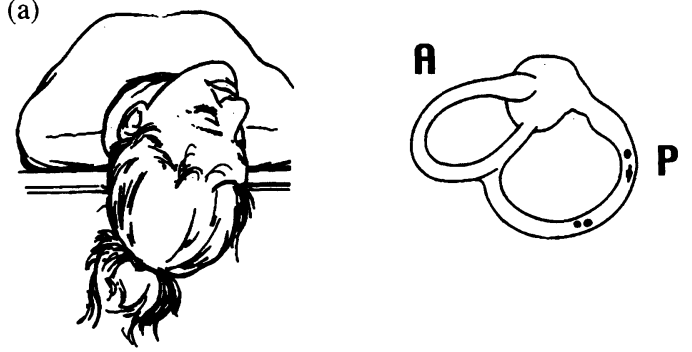

(b)

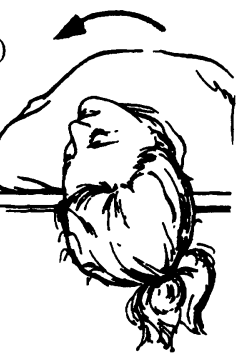

A

(c)
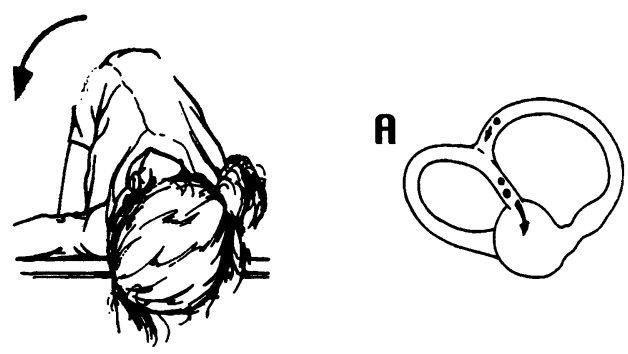

図 1 Particle Repositioning Maneuver

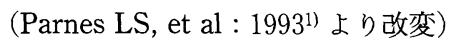

座位より眼振の誘発される懸垂頭位をとらせる $(\mathrm{a})$. 図 は患側右の場合．眼振が消失してもそのまま頭位を 2 ， 3 分維持した後,ゆっくり反対側侸位を変換させ $(\mathrm{b})$, 肩を妨いて頭位を仰臥位より $135^{\circ}$ の位置まで回旋させ る(c). やはりこの頭位を数分続けた後そのままゆっく り起きあがり座位に戻る，この時わずかに頸を前屈させ る.

左 $45^{\circ}$ に回旋させる.そして回旋させた頸が正面に戻 らないよらに注意しながらできるだけ速やかに右側卧位 をとる、このとき患者は回転性めまいを訴光, 回旋性成 分の多い眼振が認められる. この状態を 2,3 分維持す る. 次に頸が正面に戻らないように注意しながら一気に 左側臥位まで体位を変換する．この時同様の回転性めま いと眼振が生じる場合がある. この態勢で数分維持する. このあとゆっくり座位へと頭位をもどす. この時にも弱 く同様の回転性めまいと眼振が生じることがある.

これらの手技終了後, 就寝まで横にならないよらに命 じ，眠るときも施行 3 日間はできるだけ患側を下にしな 
(a)
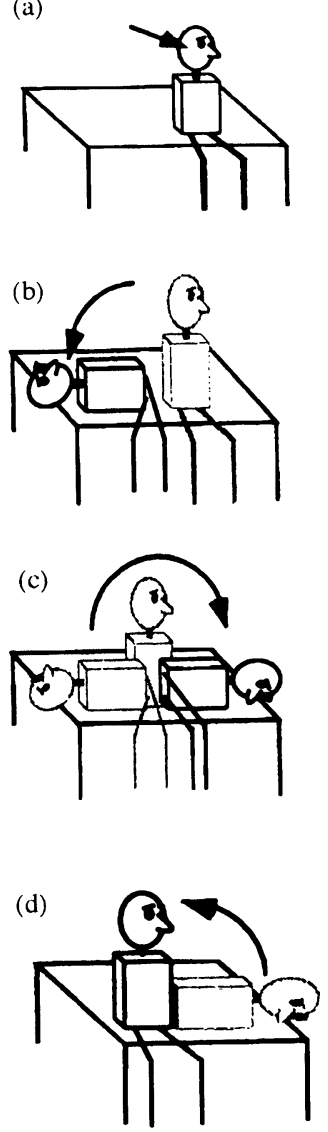
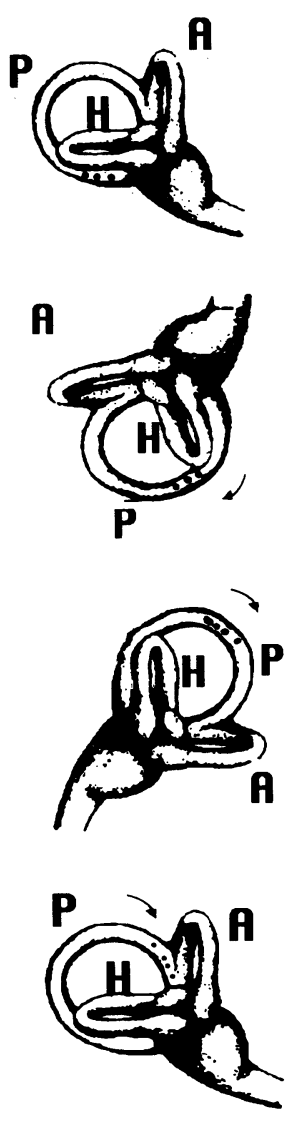

図 2 Semont Liberatory Maneuver

(Brandt T, et al : 19944) より改変)

ベッドに腰掛け頸を左に $45^{\circ}$ 回旋させる (a). 頸を回旋 させたまま急速に右側臥位をとらせる．この時頭部がべ ッドからはみ出るよらにし, 鉛直方向より $105^{\circ}$ になる よらにする (b). この頭位を 2,3 分維持させた後, 頸 が左に $45^{\circ}$ 回旋した状態を保たせたまま今度は急速に左 側臥位をとらせる $(\mathrm{c})$. この頭位をやはり数分維持させ た後ゆっくりと起きあがる.

\section{いよらにして寝るよらに指示した。}

手技施行後, 原則として 3 日後, 7 日後, 14 日後に外 来を受診させ，問診にて症状の有無を尋ね，頭位変換眼 振検査にて眼振の有無を検討した. 最終判定は 2 週間後 とし，途中の問診・検査で，3 日目にめまい・眼振とも に不変，あるいは，7日目にめまい・眼振ともにわずか に減弱のみの場合には，他方の手技に変更し，その他症 状・眼振が残存している場合にはすべて同じ手技を反復 した。

\section{結果}

表 1 に平成 5 年の頭位変換による治療非施行群, PRM 施行群, LM 施行群の性・年齢分布を示す. 非施 行群と比較して施行群はやや女性が多かったが，年齢分

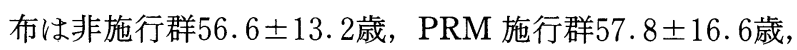
LM 施行群 $50.3 \pm 15.2$ 歳で 3 群は統計学的には差はなか った. 表 2 に発症から治療開始までの期間を示す. 非施 行群14.5土24.78日, PRM 施行群 $14.9 \pm 13.1$ 日, LM 施行群23.7土15.8日で 3 群間に統計学的差はなかった.

結果は 4 段階で評価した。すなわち, I ) 著効 : 回転 性めまい・眼振ともに完全消失. II) 有効：回転性めま い・眼振ともに消失したが浮動感が残存している． III） やや有効：回転性めまい・眼振ともに減弱したが残存し ている. N) 無効：全く回転性めまい.眼振に変化がな い.である.

表 3 は 2 週間後の短期成績を示す.ただし PRM 施行 群中 1 例は 2 週間でやや有効 (III)であったため LMに 変更， 2 例は 3 日後，7 日後に全く無効 $(\mathbb{N})$ であったた め LM に変更した。逆に LM から PRM に変更したも

表 1 年齢・性分布

\begin{tabular}{c|cc|cc|cc}
\hline \hline \multirow{2}{*}{ 年齢 } & \multicolumn{2}{|c|}{ 男性 } & 女施行群 & \multicolumn{2}{|c|}{ P R } & \multicolumn{2}{|c}{ L M } \\
\hline & & 男性 & 女性 & 男性 & 女性 \\
\hline $20 \sim 29$ & 0 & 0 & 0 & 0 & 0 & 1 \\
$30 \sim 39$ & 2 & 0 & 1 & 0 & 0 & 1 \\
$40 \sim 49$ & 3 & 4 & 1 & 5 & 0 & 1 \\
$50 \sim 59$ & 5 & 3 & 0 & 2 & 1 & 3 \\
$60 \sim 69$ & 2 & 3 & 1 & 3 & 1 & 0 \\
$70 \sim 79$ & 0 & 3 & 0 & 2 & 1 & 0 \\
$80 \sim 7$ & 1 & 0 & 2 & 0 & 0 & 0 \\
\hline 計 & 13 & 13 & 5 & 12 & 3 & 6
\end{tabular}

註 3 例は PRM の後に LM を行っているため重複して いる.

表 2 発症から治療開始までの期間

\begin{tabular}{c|c|c|c}
\hline \hline 期間 & 非施行群 & P R M & L M \\
\hline \hline 0日 - 3日 & 11 & 5 & 0 \\
3日 - 1週 & 4 & 2 & 1 \\
1週 - 2週 & 6 & 3 & 2 \\
2週 - 1月 & 2 & 2 & 2 \\
1月 - 2月 & 2 & 4 & 4 \\
2月 - & 1 & 1 & 0 \\
\hline 計 & 26 & 17 & 9
\end{tabular}

註 3 例は PRM の後に LM を行っているため重複 している. 
表 3 治療後 2 週間後の効果

\begin{tabular}{cccc}
\hline \hline & 非施行群 & P R M & L M \\
\hline \hline 有効以上 & $8 / 26$ & $13 / 15$ & $8 / 9$ \\
$(\%)$ & $(30.8 \%)$ & $(86.7 \%)$ & $(88.9 \%)$
\end{tabular}

のはなかった．その結果， 2 週間後の判定ができた症例 はPRM 15例，LM 9 例であった. 2 週間で効果 I また はII 以上を改善とみなすと, 非施行群では26例中 8 例 (30.8\%)であったのに対して，PRM 施行群では15例中 13 例 (86.7\%: $\mathrm{P}<0.01)$, LM 施行群では 9 例中 8 例 (88.9\% : $\mathrm{P}<0.01)$ で両方法とも非施行群と比較して有 意に改善率が高かった．PRM 無効でLM に変更した 3 例中 2 例は著効， 1 例はやや有効であった.

図 3 は 3 カ月間の時間経過伴う改善率の推移のグラ フである．縦軸は改善例の割合を横軸は時間経過を示す。 今回 5 月から 11 月の検討期間のらち, 11 月の症例は 3 力 月を経過して扣らず，2 週間で改善していれば「改善」 として，それ以後の経過(再発率)については考慮してい ない(ただし，観察できた範囲では一度消失しためまい ・眼振が再発した症例はない). 非施行群でも 3 力月後 の改善率は $96.2 \%$ 亿すで達する. PRM に関しては 2 週 間後に LM に変更したためその後は示していない. 残 りの 2 週間で無効であった 1 例は 3 カ月で概ね改善 (II) した. LM 施行群でやや有効 (III)であった 1 例はその後

(\%)

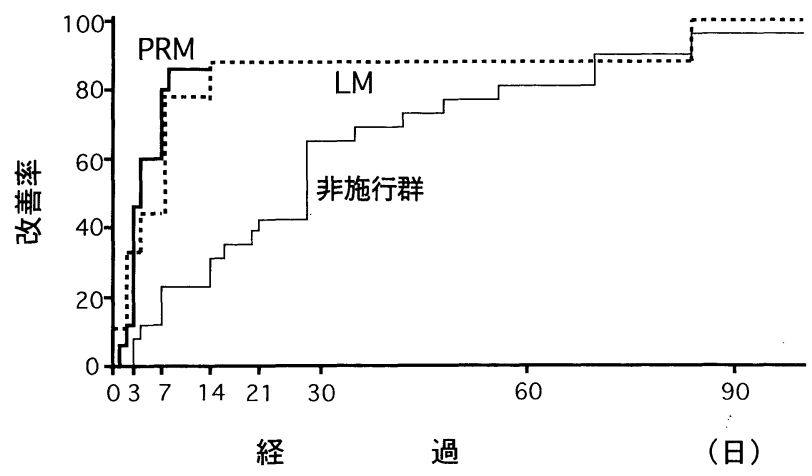

図 3 時間経過と改善率の変化

縦軸に改善例の割合，横軸に時間経過を示す，再発例は 考慮していない.PRM の非改善例は LM に変更したた め14日以後は記載せず．長期的には薬物治療群と差はな いが，頭位変換による治療法は治療期間を明らかに短縮 する。
氷見ら ${ }^{5)}$ や Brandt ら ${ }^{6)}$ の方法に準じて座位から左右の 側臥位を繰り返してとらせるリハビリテーションを行わ せることで 3 カ月後概ね軽快，社会復帰することができ た。

\section{考察}

BPPV は日常よく遭遇する疾患である。耳鼻咽喉科 ・神経耳科を受診する全めまい患者に占める割合は，鈴 木 $5^{7)} 3.1 \%$, 竹森 ${ }^{8)} 5.9 \%$, 調ら ${ }^{9)} 14 \%$, 竹腰 ${ }^{10)} 12.3 \%$, 佐々野ら ${ }^{11)} 6.5 \%$ 之施設により若干差は見られるものの メニェール病とならんで多く, しかも近年増加傾向にあ るといわれている1112).

BPPV の病態としては 1969年 Schuknecht ${ }^{13)}$ が提唱し た cupulolithiaisis の概念が長く支持されてきた。しか し，眼振の潜時や急速な眼振の減衰といった現象を完全 には説明することができず，近年これにかわって後半規 管に浮遊する小片が移動することによってめまいや眼振 が生じるという canalithiasis の概念が提唱されるよう になった14)。これを裏付ける証拠として1992年 Parnes ら ${ }^{15)}$ は BPPV の患者に対して後半規管遮断手術を行っ た際に後半規管内に浮遊物を発見したと報告した。

BPPV の治療法としては抗眩量剤やマイナートラン キライザーなどによる治療で経過をみることが多いが， こうした薬剤治療は無効であるとの報告もある16)，比較 的特殊な治療法として内耳麻醉5)17) あるいは，手術療法 として後膨大部神経切断術18), 後半規管遮断術19)などが 報告されている. しかし内耳麻酔は施行後一過性ではあ るが，めまいが強く第一選択にはならない。手術療法も 第一選択の治療法ではない，そうした中，本邦では特に リハビリテーションによる訓練療法が比較的有効とされ てきた．吉本 ${ }^{20)}$ は仰臥位の姿勢からめまい頭位(右また は左下頭位) と非めまい頭位(左または右下頭位)を繰り 返す方法を報告した．水見ら ${ }^{5)}$ はの方法と Brandt ら の方法(後述)とを参考改変し両側臥位を繰り返しとる 訓練療法を報告した．Uematsu ら ${ }^{21)}$ は座位および腹這 いの状態でいろいろな頭位变換を繰り返寸理学的療法を 報告した．しかしこれら訓練療法は何度も繰り返しめま い頭位をとる必要があり，患者の強い意志と協力を必要 とする.

Canalithiasis 説の概念をもとに後半規管内の浮遊物を 排出させようと試みたのは1980年 Brandt ら と思われる．この方法は両側卧位を繰り返しとる方法で 
あるが，後半規管の内リンパの動きを考慮しておらず， 繰り返し体位变換を行う必要があったために, 浮遊物排 出操作よりもリハビリテーションの色彩が強くなった. これを改良した方法が LM と考兄られる。この方法は 1988年 Semont ら2) が初めて紹介した治療法で, 1 回の 手技で $83.96 \%$ が，2 回行らことで $92.68 \%$ が改善したと 報告した．しかし Epley 22) はこの方法は体位变換をかな り急速に行うために乱暴な方法とし，これに変わる方法 として Canalith repositioning procedure は今回とりあげたPRM を報告した。これらはほぼ同様 の頭位変換を行ら手技であるが，前者は鎮静剤による前 処置とバイブレーターを用いる点でやや煩雑である。

これらの方法はいずれも $80 \%$ を越光る高い改善率を示 すが，複数の方法で比較した文献は少ない. Parnes ら1) はPRM を紹介するにあたって LM との比較で報告し， LM 施行群では短期・長期の観察期間でともに10例中 8 例 (80\%) であったのに対して PRM 施行群で短期34例中 30 例 (88.2\%), 長期 29 例中 $24 \%$ (82.8\%) と短期 - 長期と も汇涪同様の改善率を報告した。また Herdman ら 23$)$ は 1 回きりの操作での改善率は PRM 施行群で治瘉 $57 \%$. 改善33\%, LM 施行群で治癒70\%・改善20\%であったと 報告した。

今回の我々の結果は，2 週間の短期の観察期間では改 善以上を示した症例は PRM 施行群が15例中13例 (86.7 \%)，LM 施行群が 9 例中 8 例 (88.9\%) で薬物治療によ る従来の治療法の群26例中 8 例 $(30.8 \%)$ 上り有意に高い 改善率であった $(\mathrm{P}<0.01)$. この改善率は上述の報告と ほぼ同様の結果であった。

PRM 施行群と LM 施行群は両者の間には明らかな有 意差を認めなかったが，PRM で無効であった 3 症例の らち 2 症例が LM で著効, 1 例がやや有効といら結果 であり，LMの方が特に優れていると考えられた。

Epley が乱暴な方法と評するLM であるが，今回の検 討では特に大きな支障もなく，めまい自体も耐えられる 範囲内のものであった.

これら $2 つ の$ 頭位変換による治療法の使い分けである が，今回の結果をふま兄て両方の手技が施行可能であれ ばLMを第一選択とするのが良いと思われる。ただし 短時間ではあるがかなり強い回転性めまいを生じるので この疾患をもつ患者の中には頭位変換を極刃て嫌い不安 が強い場合がある.こうした場合まずはPRM にて経過 を見ていくのも 1 つの方法であると思われる。 また頭位
変換による治療法で完全に眼振が消失しない場合にこそ 訓練療法・リハビリテーションを行っていけばよいと考 える。

$$
\text { まとめ }
$$

1. Particle Repositioning Maneuver (PRM) と Semont Liberatory Maneuver (LM) そついて有効性を検討 した.

2. 両者ともに 1 回または 2 回の手技で $80 \%$ 以上の有 効率を示した.

3. 従来の治療法と比較して明らか飞治療期間を短縮 することができた.

4. PRM が無効の症例でも LM が有効な症例があり, LM が優れていると思われた.

本論文の要旨は, 第59回日耳鼻京滋合同地方部会(平成 6 年 12月10日)に㨟いて発表した.

\section{参考文献}

1) Parnes LS and Price-Jones RG: Particle repositioning maneuver for benign paroxysmal positional vertigo. Ann Otol Rhinol Laryngol $102: 325 \sim 330,1993$.

2 ) Semont A, Freyss G, Vitte E : Curing the BPPV with a liberatory meneuver. Adv Otorhinolaryngol $42: 290 \sim 293$, 1988.

3 ) 日本平衡神経科学会編：めまいの基準化のための資料. Equilibrium Res 47 :257, 1988.

4 ) Brandt $T$, Steddin $S$ and Daroff RB : Therapy for benign paroxysmal postioning vertigo, revisited. Neurology 44 : 796 800, 1994.

5 ) 氷見徹夫, 志藤文明, 山中 昇, 他: 良性発作性頭位眩暈 (症)に対するリドカイン(キシロカイン)内耳麻酔 : 耳鼻臨 床 $78: 1577 \sim 1585,1985$.

6 ) Brandt $T$ and Daroff RB : Physical therapy for benign paroxysmal postional vertigo, Arch Otolaryngol $106: 484$ $\sim 485,1980$.

7 ) 鈴木 衛, 杉本嘉朗, 川真田聖一, 他 : 良性発作性頭位眩 暈症の臨床的観察. 耳鼻 $25: 453 \sim 457,1979$.

8 ）竹森節子：良性発作性頭位眩量症の臨床. Equillibrium Res $39: 262 \sim 265,1980$.

9 ) 調 重昭, 河野正司, 安元義博, 他 : 発作性頭位眩量症の 検討. 耳鼻臨床 75 増 $1: 187 \sim 192,1982$.

10）竹腰昌明：良性発作性頭位眩暈症. 耳鼻 $32: 474 \sim 479$, 1986.

11）佐々野利春, 中島成人, 重野浩一郎, 他 : 良性発作性頭位 
眩量症の臨床的観察. Equillibrium Res $46: 267 \sim 271,1987$.

12）徳増厚二, 斉藤 彰, 西端慎一, 他：良性発作性頭位めま い症の診断と発生頻度について. 耳鼻臨床 78 増 $6: 2615$ $\sim 2621,1985$.

13) Schuknecht HF : Cupulolithiasis. Arch Otolaryngol 90 : 765 778, 1969.

14) Hall SF, Ruby RRF and McCure JA : The mechanics of benign paroxysmal vertigo. J Otolaryngol $8: 151 \sim 158$, 1979.

15) Parnes LS and McCure JA : Free-floating endolymph paricles ; a new operative finding during posterior semicircular canal occlusion. Laryngoscope 102 : 988 992, 1992

16) McClure JA and Willett JM : Lorazepam and diazepam in the treatment of benign paroxysmal vertigo. $J$ Otolaryngol $9: 472 \sim 477,1980$.

17）神尾友和, 江上徹也, 鈴木淳一：内耳の麻酔と破壊による 頭位眩量症の診断と治療. 耳鼻臨床 66: 619 629, 1973.

18) Gacek RR : Singular neurectomy update. II; review of 102 cases. Laryngoscope $101:$ 855 862, 1991.
19) Parnes LS and McClure JA : Posterior semicircular canal occlusion for intractable benign paroxysmal positional vertigo. Ann Otol Rhinol Laryngol $99: 330 \sim 334,1990$.

20）吉本 裕：良性発作性頭位眩量症, 前庭神経炎に対する保 存的治療. 耳鼻 $29: 660 \sim 663,1983$.

21) Uematsu $M$ and Umeda $Y$ : Physical treatment of benign paroxysmal positional vertigo. Acta Otolaryngol (Stockh) Suppl $481:$ 624 625, 1991.

22) Epley JM : The canalith repositioning procedure; for treatment of benign paroxysmal positional vertigo. Otolaryngol Head Neck Surg 107 : 399 404, 1992.

23) Herdman SJ, Tusa RJ, Zee DS et al. : Single treatment approaches to benigh paroxysmal postional vertigo. Arch Otolaryngol Head Neck Surg 119 : 450 454, 1993.

$\left.\begin{array}{l}\text { 原稿受付 : 平成 } 7 \text { 年 } 1 \text { 月 } 12 \text { 日 } \\ \text { 原稿採択 : 平成 } 7 \text { 年 } 3 \text { 月 } 24 \text { 日 急載 } \\ \text { 別刷請求先 : 板谷隆義 } \\ \text { ₹ } 650 \text { 神戸市中央区港島中町 } 4-6 \\ \text { 神戸市立中央市民病院耳鼻咽喉科 }\end{array}\right)$

